\title{
Sejarah Tragedi Jumat Kelabu 23 Mei 1997
}

\author{
Muhammad Rival \\ Email: $2010128310001 @$ mhs.ulm.ac.id \\ Program Studi Pendidikan IPS Fakultas Keguruan dan Ilmu Penidikan \\ Universitas Lambung Mangkurat \\ Banjarmasin
}

\begin{abstract}
Abstrak
Konflik sosial merupakan hal yang dapat terjadi pada kondisi tertentu sehingga dapat menyebabakan kerusuhan, dampak dari kerusuhan ini dapat berupa korban manusia serta kerugian dalam bentuk material. Tragedy jumat kelabu pada 23 Mei 1997 terdapat konflik dan kerusuhan yang disebabkan oleh kampanye yang dilakukan oleh partai politik yang mengganggu kekhusukan ibadah sholat jumat serta berbagai hal yang dapat memicu konflik lain.
\end{abstract}

\section{PENDAHULUAN}

Kerusuhan dan konflik sosial merupakan suatu hal yang didasarkan atas perbedaan pendapat atau keyakinan akan suatu hal yang tidak dapat disepakati secara bersama. Konflik ini dapat dpengaruhi oleh beberapa faktor yang dapat meliputi faktor-faktor sosial politik dan ekonomi di Indonesia sendiri terdiri dari banyaknya suku bangsa dengan segala keanekaragamannya, agama dan kelompok tersebut memilik potensi akan terjadinya konflik sosial yang dapat dilatar belakangi oleh agama maupun politik, budaya dan etnik. Karena Indonesia merupakan masyarakat majemuk yang dimana kita dihadapkan oleh keberagaman sehingga berbagai pertikaianpun akan dapat bahkan sering terjadi. Hal ini menunjukan bahwa kita tidak hanya berda pada persoalan antar dua etk, namun lebih rumit dari itu berdasarkan struktur masyarakat Indonesia mencerminkan sistem sosial budaya yang majemuk, baik secara horizontal maupun vertical. Secara horizontal yaitu dengan kenyataan bahwa adanya kesatuan-kesatuan entitas yang didasari perbedaan suku bangsa, adat, agama, bahasa, dan ciri-ciri kedaerahan lainnya. Sedangkan secara vertical ditandai dengan perbedaan-perbedaan sosial yang cukup tajam. Peran pemerintah sebagai jembatan 
diamana pemerintah daerah setempat dapat melakukan pengawasan dan control terhadap mayarakat sehingga dapat mencegah ataubahkan mengatasi konflik.

\section{SEJARAH PENYEBAB TERJADINYA KONFLIK}

Konflik merupakan peristiwa yang sangat mungkin dapat terjadi didalam ubungan interaksi, pada setiap individu mempunyai potensi konflik yang ada didalam bawah sadarnya, potensi konflik ini akan memicu terjadinya tindakan konflik apabila terdapat situasinya yang memungkinkan. konflik biasa terjadi karena adanya perbedaan kepentingan. Dalam setiap peristiwa suatu konflik selalu trbentuk sebuah polarisai pihakpihak yang berseteru. Namun tidak selamanya konflik itu bersifat negative. Karena konflik juga dapat menciptakan tatanan sosial yang lebi baik jika berlangsungsecara terkendali. Kota Banjarmasin merupakan salah satu kota di Indonesia yang dikenal dengan karakter masyarakatnya yang hidup rukun, harmonis dan religious, namun hal ini bukan tidak mengindahkan terjadinya konflik bahkan terjadi keruhsuhan seperti yang terjadi pada 23, Mei 1997.

Pada saat menjelang pemilu pada Tahun 1997 di awali dengan gangguan ibadah sholat jumat sekitar di Masjid Noor oleh partisipan kampanye dari partai Golkar pada saat itu yang menjadi pemicu terjadinya konflik dan kerusuhan di Kota Banjarmasin dan yang menjadi target pada kampanye tersebut meliputi buruh, pengojek, dan tukang becak.. Kemarahan masyarakat pada kala itu terjadi dibeberapa tempat di Banjarmasin yang merasa kegiatan ibadahnya menjadi terganggu dan geram atas kejadian itu oleh tiga partai politik yakni Golkar, PPP, dan PDIP yang sedang dalam melakukan kampanye menjelang pemilihan anggota Legislatif. Ketidaksukaan dan rasa geram inilah yang menjadi penyebab dari terjadinya tragedi Jumat Kelabu oleh para kampanye yang berkeliling kota dengan menggunakan motor sehingga membuat kebisingan yang mengganggu ibadah.

\section{AKIBAT DARI KONFLIK JUMAT KELABU}

Akibat dari penyebab terjadinya kerusuhan merupakan dampak yang dihasilkan oleh konflik yang terjadi karena adanya suatu permasalahan yang terjadi sehingga dapat menimbulkan kerusuhan. Seusai sholat jumat terjadi kerusuhan di depan kantor DPD Golkar Kalsel. Berita tersebut langsung menyebar dan masa pun berdatangan dan terjadilah bentrok yang rata rata berasal dari pemuda pancasila dan FKPPI. Selain kampanye yang 
memanas terdapat pula selembaran yang mengajak massa untuk bermusuhan dan kerusuhan. Dan konflik ini berlangsung hingga malam hari dan aliran listrik pada kala itu menjadi padam sehingga suasananya terasa semakin mencekam.

Akibatnya banyak korban manusia akibat dari konflik tersebut berdasarkan data kepolisian terdapat 123 orang tewas. Sedangkan berdasarkan versi keamanan menyebutkan 142 orang meninggal dan berbagai versi lainnya 133,142,155,156, dan 170. Kemudian terdapat jumlah orang yang dinyatakan luka-luka yang berjumlah 118 orang yang berasil diidentifikasi dari berbagai rumah sakit. Dan 179 orang dinyatakan hilang yang kemungkinan merupkan bagian dari jumlah korban yang tidak dapat di identifikasi.

Akibat dari kerusuhan ini juga menyebabkan berbagai kerusakan dibeberapa tempat di Banjarmasin meliputi 5 pusat perbelanjaan (4 hanagus terbakar dan 1 rusak serta dijarah), 3 sarana pendidikan yang rusak, 11 Greja (1 hangus terbakar, dan 10 lainnya rusak), 5 bank (1 dibakar dan dijarah, dan 4 bank rusak), 3 Vihara 1 dibakar sisanya rusak, 1 kelaten rusak, 1 panti jompo rusak, 1 apotek terbakar, 2 hotel (hotel Arum dibakar dan Hotel Barito dirusak), 151 rumah penduduk sengaja di bakar dan ikut terbakar, 5 Ruko meliputi 1 terbakar dan sisanya rusak, 2 kantor swasta Sengaja dibakar dan terbakar, 144 toko Dirusak dan terbakar ini tersebar di beberapa tempat, 36 mobil (20 dibakar dan sisanya rusak berat), 1 truk Dibakar, 47 sepeda motor 36 dibakar dan 11 rusak berat, 9 sepeda terbakar, 151 rumah makan Terbakar

\section{SIMPULAN}

Konflik merupakan suatu permasalahn sosial dimana terdapat perselisihan antara suatu individu dan atau kelompok yang biasanya didasarkan karena adanya perbedaan dan terdapat perselisihan yang mungkin meliputi sara. Indonesia merupakan masyarakat yang majemuk yang dimana kita dihadapkan oleh keberagaman sehingga berbagai pertikaianpun akan dapat bahkan sering terjadi. Adapun penyebab terjadinya kerusuhan pada 23 Mei 1997 yang meliputi rute kampanye, Basis Partai, tidak menghormati kegiatna sholat jumat yang dilaksanakan pada siang itu, Agresifitas Massa Peserta Kampanye. Kemudian terdapat banyak sekali korban manusia baik yang meninggal dunia, luka-luka, dan dinyatakan hilang. Selain itu terdapat pula tempat-tempat umun dan bangunan-bangunan yang menjadi sasaran massa sehingga menyebabkan kerusakan. 


\section{REFERENSI}

Efendi, I., Prawitasari, M., \& Susanto, H. (2021). Implementasi Penilaian Pembelajaran Pada Kurikulum 2013 Mata Pelajaran Sejarah. Prabayaksa: Journal of History Education, 1(1), 21-25.

Nuesasongko Pekik. (2011). Atlas Tematik: Kota Banjarmasin, Klaten: PT Intan Prawira..

Sulistyo, Hermawan, (1999). "Anaraki Enam Jam: Rekonstruksi Kerusuhan Jumat Membara di Banjarmasin”, dalam Haris Syamsudin, kecurangan dna perlawanan Rakyat dalam Pemilihan Umum 1997, Jakarta: Yayasan Obor Indonesia.

Suwariyati, Titik, (2003) "Konflik-konflik sosial Bernuansa Agama di Berbagai Komunita: Kasus Kerusuhan Sosial di Banjarmasin 1997”. 